\title{
UPGRADING OF POWER QUALITY BY USING TCR \& SHPF
}

\author{
Mr. Bhaskar C \\ Assit. Professor EEE \\ Sir MVIT., Bangalore
}

\author{
Dr C V Mohan \\ Assoc. Professor, EEE \\ Sir MVIT, Bangalore
}

\begin{abstract}
This project proposes a combined system of a Thyristror-controlled reactor (TCR) and a shunt hybrid power filter (SHPF) for harmonic and reactive power compensation. The SHPF is the combination of a small-rating active power filter (APF) and a fifth-harmonic-tuned $L C$ passive filter. The tuned passive filter and the TCR form a shunt passive filter (SPF) to compensate reactive power. The small-rating APF is used to improve the filtering characteristics of SPF and to suppress the possibility of resonance between the SPF and line inductances. The simulation and experimental results are found to be quite satisfactory to mitigate harmonic distortions and reactive power compensation.
\end{abstract}

KEYWORDS: Active filter, passive filters, tcr, reactive power compensation, simulation.

\section{INTRODUCTION}

Now a day's electric power supply distribution systems, there is a sharp rise in the use of single phase and three-phase non-linear loads such as computer power supplies, commercial lighting, rectifier equipment in telecommunication networks, domestic equipment's like TVs, ovens, adjustable speed drives (ASD) and asynchronous ac-dc links as in wind, and wave electric power generation systems. These nonlinear loads generally have solid state control of electric power and draw non-sinusoidal unbalanced currents from ac mains resulting in harmonic injection, reactive power burden, and unstable loading.

Further, they cause poor power factor, low efficiency, neutral conductor bursting and interference with nearby communication networks. Conventionally passive L-C filters were used to reduce harmonics, and power capacitors were employed to improve the power factor of the ac mains, but they have the limitations of fixed compensation characteristics and large size, and can also excite resonance conditions. Recently the use of active filters and hybrid filters for power quality improvements is on the rise.
A new combination of a shunt hybrid power filter SHPF and a TCR is proposed to suppress current harmonics and compensate the reactive power generated from the load. The hybrid filter consists of a series connection of a small-rated active filter and a fifth-tuned $L C$ passive filter. In the proposed topology, the major part of the compensation is supported by the passive filter and the TCR while the APF is meant to improve the filtering characteristics and damps the resonance, which can occur between the passive filter, the TCR, and the source impedance.

The shunt APF when used alone suffers from the high kilovolt ampere rating of the inverter, which requires a lot of energy stored at high dc-link voltage, the standard hybrid power filter is unable to compensate the reactive power because of the behavior of the passive filter. Hence, the proposed combination of SHPF and TCR compensates for unwanted reactive power and harmonic currents. In addition, it reduces significantly the volt-ampere rating of the APF part. The control method of the combined compensator is presented. A control technique is proposed to improve the dynamic response and decrease the steady-state error of the TCR. It consists of a PI controller and a lookup table to extract the required firing angle to compensate a reactive power consumed by the load.

\section{PROBLEMS FROM HARMONICS, REACTIVE POWER AND NEED OF COMPENSATION}

Power system problems related to harmonics are rare but it is possible for a number of undesirable effects to occur. High levels of harmonic distortion can cause such effects as increased transformer, capacitor, motor or generator heating, failure of electronic equipment relies on zero voltage crossing detection or is sensitive to wave shape, incorrect readings on meters, malfunction of protective relays, interference with telephone circuits, etc. The likelihood of such abnormal effects greatly increases on resonant condition occurs. Resonance occurs when a harmonic frequency produced by a nonlinear load closely coincides with a power system 


\section{International Journal of Engineering Applied Sciences and Technology, 2019 Vol. 4, Issue 7, ISSN No. 2455-2143, Pages 396-401 \\ Published Online November 2019 in IJEAST (http://www.ijeast.com)}

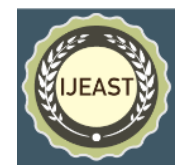

natural frequency. Reactive power is required to maintain the voltage to deliver active power through transmission lines. Motor loads and other loads require reactive power to convert the flow of electrons into useful work. When there is not enough reactive power, the voltage sags down and it is not possible to push the power demanded by loads through the lines.

The implementation of Active Filters in this modern electronic age has become an increasingly essential element to the power network. With advancements in technology since the early eighties and significant trends of power electronic devices among consumers and industry, utilities are continually pressured in providing a quality and reliable supply. Power electronic devices such as computers, printers, faxes, fluorescent lighting and most other office equipment all create harmonics. These types of devices are commonly classified collectively as nonlinear load. Nonlinear loads create harmonics by drawing current in abrupt short pulses rather than in a smooth sinusoidal manner. The major issues associated with the supply of harmonics to nonlinear loads are severe overheating and insulation damage. Increased operating temperatures of generators and transformers degrade the insulation material of its windings. If this heating were continued to the point at which the insulation fails, a flashover may occur should it be combined with leakage current from its conductors. This would permanently damage the device and result in loss of generation causing widespread blackouts. One solution to this foreseeable problem is to install active filters for each nonlinear load in the power system network. Although presently very uneconomical, the installation of active filters proves indispensable for solving power quality problems in distribution networks such as harmonic current compensation, reactive current compensation, voltage sag compensation, voltage flicker compensation and negative phase sequence current compensation. Ultimately, this would ensure a polluted free system with increased reliability and quality.

\section{GENARAL BLOCK DIAGRAM}

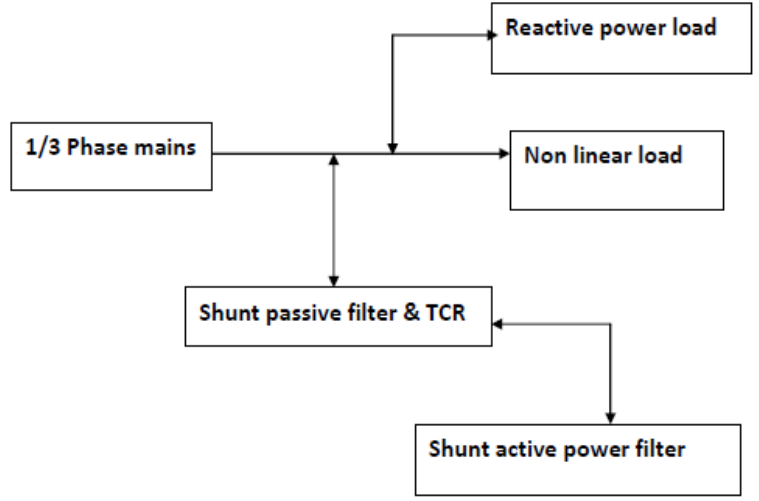

Fig 1 Block diagram

The above figure shows the block of the proposed model hear we can saw that three phase line will be used with line parameters for that line connect nonlinear load as shown and then reactive load also used hear,this loads produces harmonics and resonance problem in line, TCR $\mathrm{s}$ will be help full to compensate LC filter is used to tune the 5th harmonics, active power filter will be shown hear it will be working as a rectifier and as well as a inverter the input will be rectified and stores in capacitor when we need compensation this will be inverted and helps to compensate we used hear passive and TCR hear it will be helps active filter helps over come from high kilovolt ampere rating of the inverter problem. So by using this method we can overcome from harmonic, resonance and high kilovolt ampere rating inverter problem.

\section{SIMULATION FOR NON LINEAR AND REACTIVE LOAD}

The bellow figure shows the simulation of the nonlinear and reactive load and its output shown.

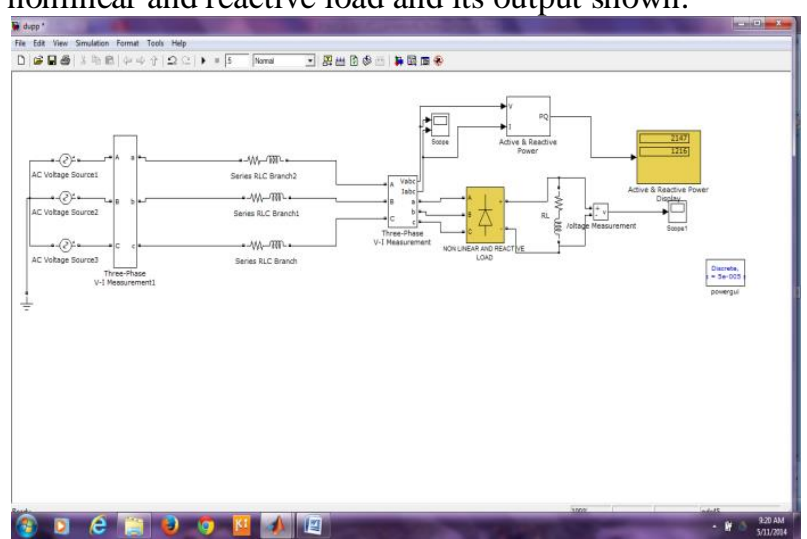

Fig 2. simulated diagram of nonlinear and reactive load 


\section{International Journal of Engineering Applied Sciences and Technology, 2019 \\ Vol. 4, Issue 7, ISSN No. 2455-2143, Pages 396-401 \\ Published Online November 2019 in IJEAST (http://www.ijeast.com)}

The above figure shows the simulation of the nonlinear and reactive load hear we can see that three phase line will be used with line parameters for that line connect nonlinear load as shown for nonlinear load hear used diode circuit and then reactive load also used hear for reactive load used inductor, this loads produces harmonics and reactive power problem in line, by using different measuring devises hear measure the THD reactive power etc. The distorted wave form and then the THD for all phases shown below.

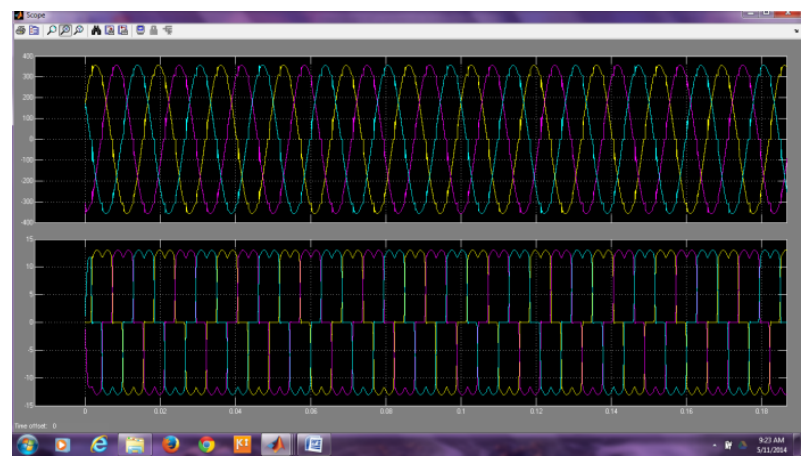

Fig3. Distorted wave form due to non linear and reactive load

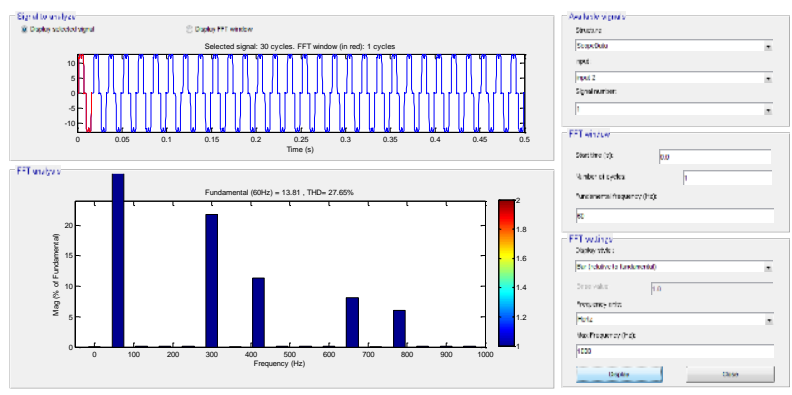

Fig4. THD of phase one

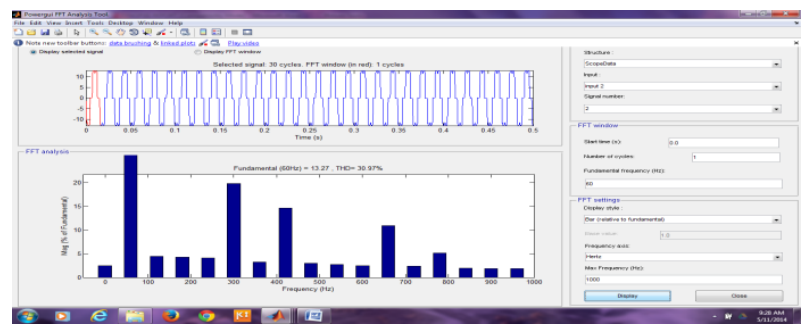

Fig5. THD of phase two

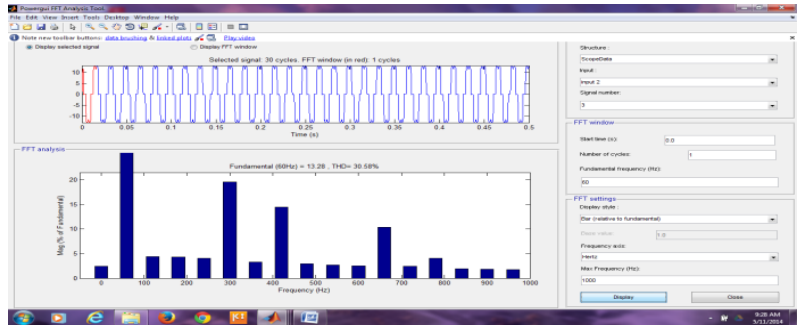

Fig6. THD of phase three

In this project work linear load is designed for the THD and reactive power values are:

\begin{tabular}{|l|l|}
\hline \multicolumn{1}{|c|}{ THD } & $\begin{array}{l}\text { Phase } 1=27.65 \% \\
\text { Phase } 2=30.97 \% \\
\text { Phase 3=30.58\% }\end{array}$ \\
\hline ACTIVE POWER & $2147 \mathrm{~W}$ \\
\hline REACTIVE POWER & $1216 \mathrm{VAR}$ \\
\hline
\end{tabular}

Table 1: THD, active \&Reactive power values

\section{PROPOSED METHOD}

The bellow figure shows the simulation of the proposed method. It shows that different measuring equipment's and nonlinear, reactive load and for harmonic reduction and SHPF and TCR shown.

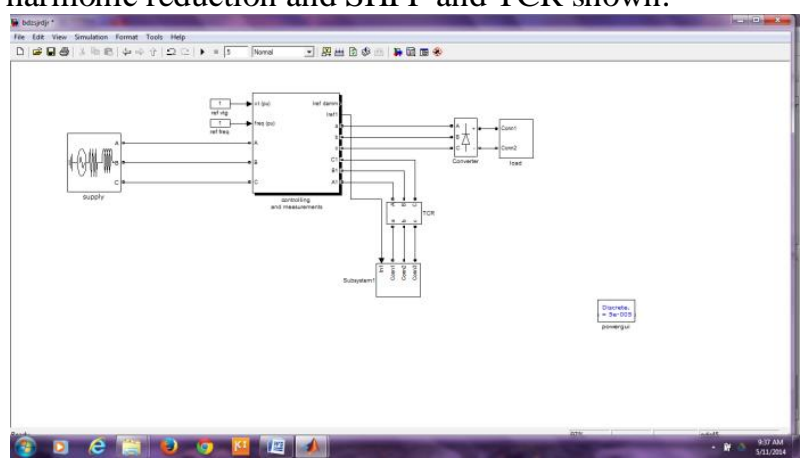

Fig 7. Proposed Simulation

The above figure shows that the proposed method simulation using different filters, first hear designed the three phase line parameters then measurement and control block shown hear we measure active and reactive power then controls shunt active power Thyristror the detailed shown fig 10 for controlling of the shunt active power filters hysteresis control method used then designed TCR this will be helps to control reactive power this TCR consist of the Thyristror inductor capacitor then used LC passive filter for compensating $3^{\text {rd }}$ and $5^{\text {th }}$ harmonic shown in fig7.1.2 and 7.1.3 finally hear designed shunt active power filter this is Thyristror circuit it can be act as rectifier and 


\section{International Journal of Engineering Applied Sciences and Technology, 2019 \\ Vol. 4, Issue 7, ISSN No. 2455-2143, Pages 396-401 \\ Published Online November 2019 in IJEAST (http://www.ijeast.com)}

inverter also rectified and stored in capacitors then inverted and injected to line as a pat of compensation. So finally by using this method we compensate harmonic and reactive power relevant wave form shown below.

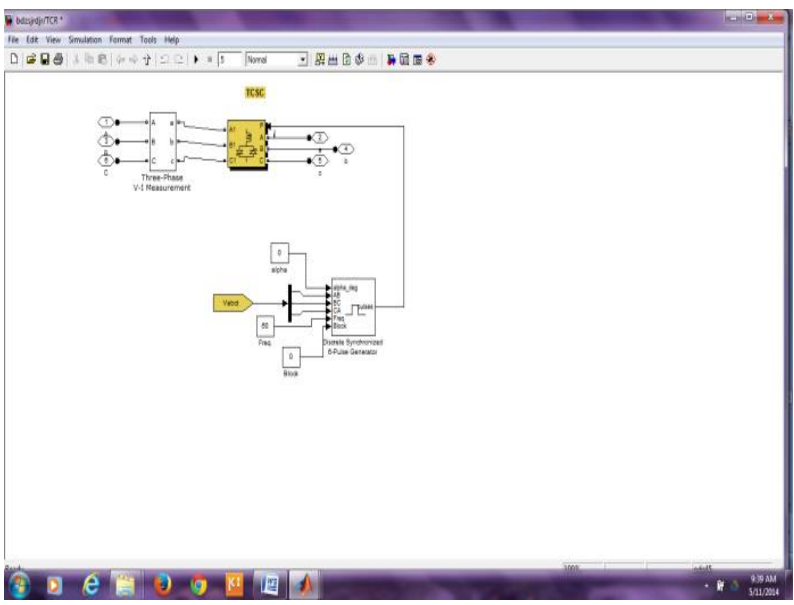

Fig 8. Design of TCRC

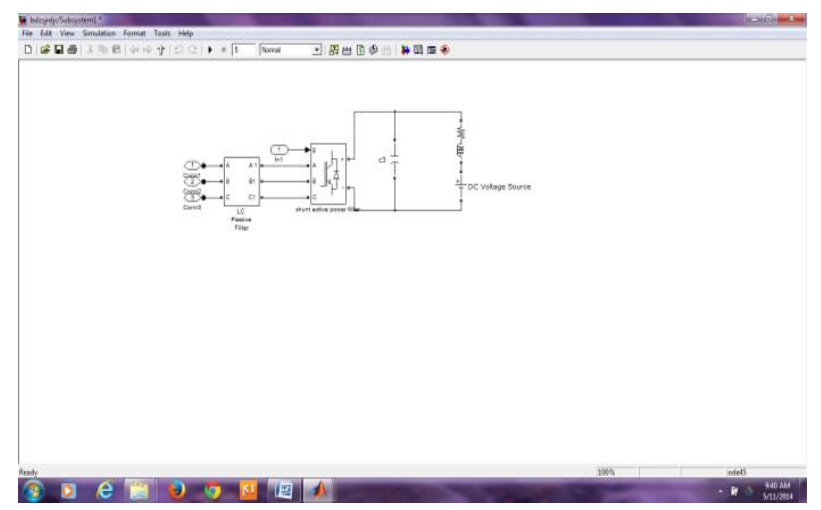

Fig 9. Design shunt active filter

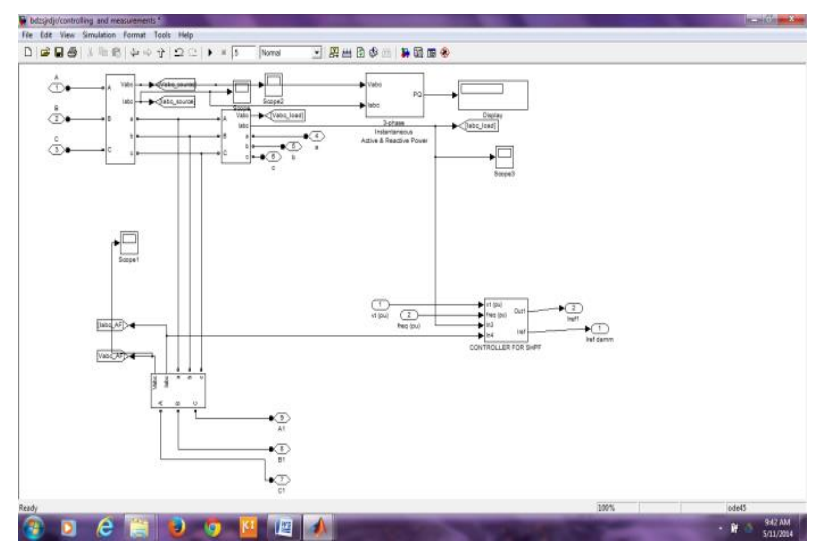

Fig 10. Design of Measurement and control system Bellow table shows the designing calculated parameters.

\begin{tabular}{|l|l|}
\hline $\begin{array}{l}\text { Line to line source } \\
\text { voltage \& frequency }\end{array}$ & $\mathrm{Vsl}-\mathrm{l}=208 \mathrm{v} . \mathrm{fs}=60 \mathrm{hz}$ \\
\hline Line impedance & $\mathrm{Ls}=0.5 \mathrm{mh}, \mathrm{Rs}=0.1 \mathrm{ohm}$ \\
\hline $\begin{array}{l}\text { Nonlinear and } \\
\text { reactive load }\end{array}$ & $\mathrm{L} 1=10 \mathrm{mh}, \mathrm{RL} 1=27 \mathrm{ohm}$ \\
\hline $\begin{array}{l}\text { Passive filter } \\
\text { parameter }\end{array}$ & $\mathrm{Lpf}=1.2 \mathrm{mh}, \mathrm{Cpf}=240 \mu \mathrm{f}$ \\
\hline $\begin{array}{l}\text { Active } \\
\text { parameter }\end{array}$ & $\mathrm{Cdc}=3000 \mu \mathrm{f}, \mathrm{Rdc}=1 \mathrm{k}$ \\
\hline $\begin{array}{l}\text { DC bus voltage of } \\
\text { SHAF }\end{array}$ & $\mathrm{Vdc}=50 \mathrm{~V}$ \\
\hline $\begin{array}{l}\text { Cut of frequency for } \\
\text { low pass filter }\end{array}$ & $\mathrm{Fc}=70 \mathrm{~Hz}$ \\
\hline TCR inductance & $\mathrm{Lt}=25 \mathrm{mh}$ \\
\hline
\end{tabular}

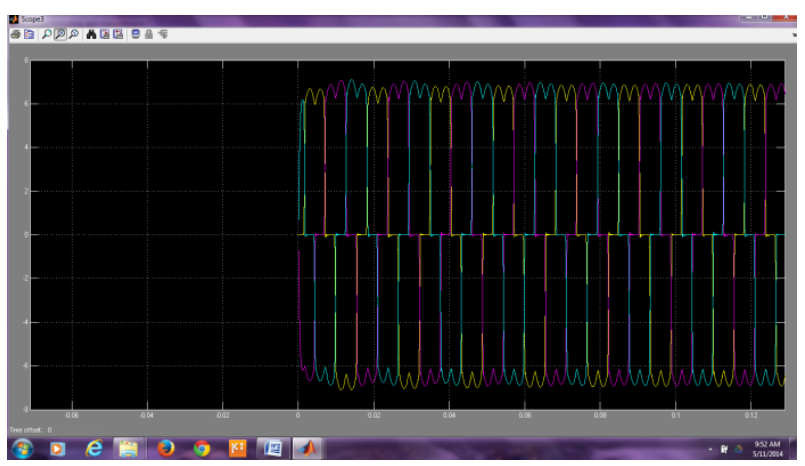

Fig 11. Line current before compensation

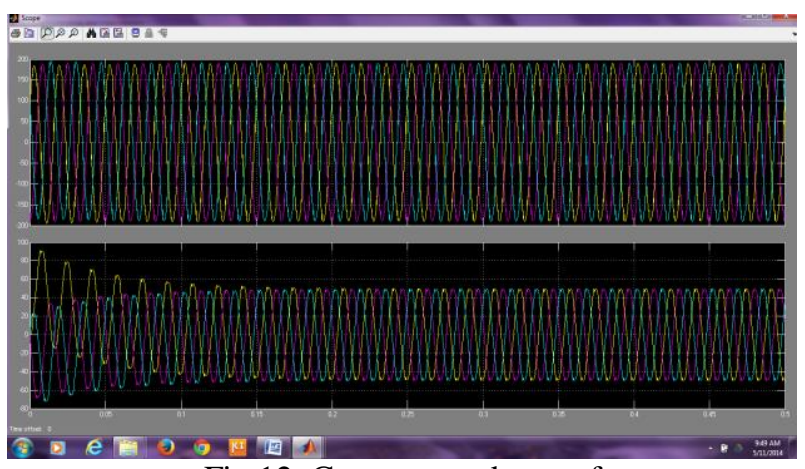

Fig 12. Compensated wave form 


\section{International Journal of Engineering Applied Sciences and Technology, 2019 Vol. 4, Issue 7, ISSN No. 2455-2143, Pages 396-401 \\ Published Online November 2019 in IJEAST (http://www.ijeast.com)}

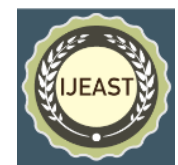

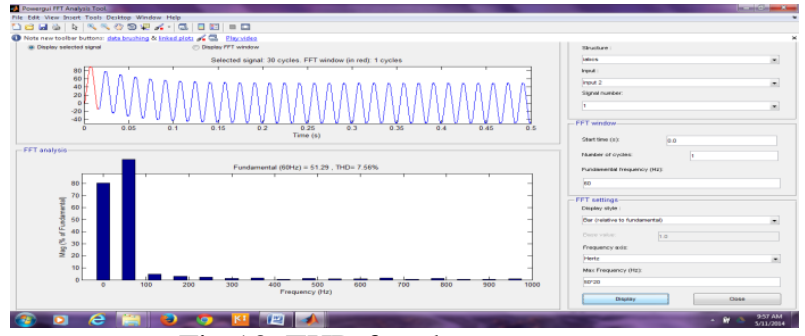

Fig 13. THD for phase one

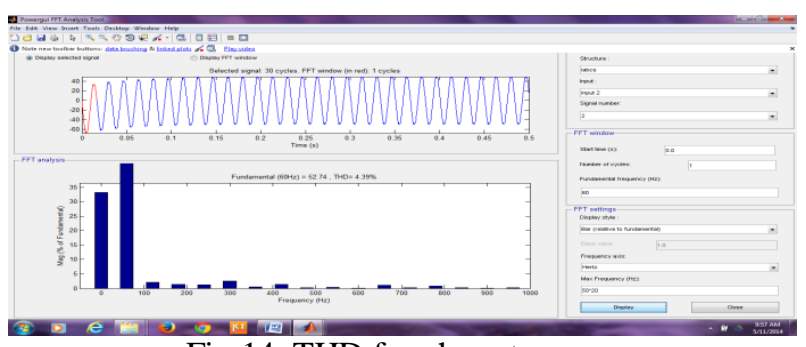

Fig 14. THD for phase two

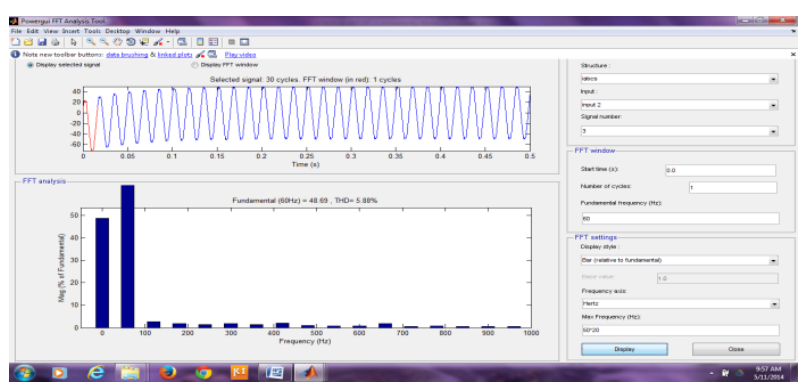

Fig 15. THD for phase three

In bellow table shows that the THD for all three phases and active and reactive power so hear shows that harmonic and reactive power is compensated.

In bellow table shows that the THD for all three phases and active and reactive power so hear shows that harmonic and reactive power is compensated.

\begin{tabular}{|l|l|}
\hline THD & $\begin{array}{l}\text { Phase } 1=7.56 \% \\
\text { Phase 2=4.39\% } \\
\text { Phase 3=5.88\% }\end{array}$ \\
\hline ACTIVE POWER & $5087 \mathrm{~W}$ \\
\hline REACTIVE POWER & $13.5 \mathrm{VAR}$ \\
\hline
\end{tabular}

Table 2: THD \& Reactive power values

\section{CONCLUSION}

In this paper, a SHPF-TCR compensator of a TCR and a SHPF has been proposed to achieve harmonic elimination and reactive power compensation. The shunt active filter and SPF have a complementary function to improve the performance of filtering and to reduce the power rating requirements of an active filter. From the proposed SHPF \& TCR compensator the current harmonic and can be eliminated effectively and also reactive power can be compensated under study \& transient condition for verity of load.

\section{REFERENCES}

[1] A. Hamadi, S. Rahmani, and K. Al-Haddad, "A hybrid passive filter configuration for VAR control and harmonic compensation," IEEE Trans. Ind. Electron., vol. 57, no. 7, pp. 2419-2434, Jul. 2010.

[2] P. Flores, J. Dixon, M. Ortuzar, R. Carmi, P. Barriuso, and L. Moran, "Static Var compensator and active power filter with power injection capability, using 27-level inverters and photovoltaic cells," IEEE Trans. Ind. Electron., vol. 56, no. 1, pp. 130-138, Jan. 2009.

[3] H. Hu, W. Shi, Y. Lu, and Y. Xing, "Design considerations for DSPcontrolled $400 \mathrm{~Hz}$ shunt active power filter in an aircraft power system," IEEE Trans. Ind. Electron., vol. 59, no. 9, pp. 3624-3634, Sep. 2012.

[4] X. Du, L. Zhou, H. Lu, and H.-M. Tai, "DC link active power filter formthree-phase diode rectifier," IEEE Trans. Ind. Electron., vol. 59, no. 3, pp. 14301442, Mar. 2012.

[5] M. Angulo, D. A. Ruiz-Caballero, J. Lago, M. L. Heldwein, and

S. A. Mussa, "Active power filter control strategy with implicit closedloop current control and resonant controller," IEEE Trans.

[6] X. Wang, F. Zhuo, J. Li, L. Wang, and S. Ni, "Modeling and control of dual-stage high-power multifunctional PV system in d-q-0 coordinate," IEEE Trans. Ind. Electron., vol. 60, no. 4, pp. 1556-1570, Apr. 2013.

[7] J. A. Munoz, J. R. Espinoza, C. R. Baier, L. A. Moran, E. E. Espinosa, P. E. Melin, and D. G. Sbarbaro, "Design of a discrete-time linear control strategy for a multicell UPQC," IEEE Trans. Ind. Electron., vol. 59, no. 10, pp. 3797-3807, Oct. 2012. 
[8] L. Junyi, P. Zanchetta, M. Degano, and E. Lavopa, "Control design and implementation for high" performance shunt active filters in aircraft power grids," IEEE Trans. Ind. Electron., vol. 59, no. 9, pp. 36043613, Sep. 2012.

[9] Y. Tang, P. C. Loh, P. Wang, F. H. Choo, F. Gao, and F. Blaabjerg, "Generalized design of high performance shunt active power filter with output LCL filter," IEEE Trans. Ind. Electron., vol. 59, no. 3, pp. 1443-1452, Mar. 2012.

[10] Z. Chen, Y. Luo, and M. Chen, "Control and performance of a cascaded shunt active power filter for aircraft electric power system," IEEE Trans. Ind. Electron., vol. 59, no. 9, pp. 3614-3623, Sep. 2012. 